\title{
Mechanism by which ammonium fertilizers kill tall larkspur
}

\author{
M.H. RALPHS, L. WOOLSEY, AND J.E. BOWNS
}

Authors are Rangeland Scientist, USDA/ARS Poisonous Plant Lab, 1150 E. 1400 N., Logan Utah 84341; Range Conservationist, USDA/NRCS, Filmore Utah; and Professor, Southern Utah Univ., Cedar City Utah.

\begin{abstract}
Environmental concerns of using pesticides on public lands have greatly reduced the use of herbicides to control tall larkspur (Delphinium barbeyi Huth). An alternative method of control used ammonium sulfate placed at the base of individual plants. The objective of this study was to determine the mechanism by which fertilizers kill tall larkspur. We hypothesize the salt from the fertilizers kill the plant. We applied ammonium sulfate, ammonium nitrate and sodium chloride at equivalent salt concentrations and evaluated their effect on tall larkspur plants. There was no difference among treatments in larkspur mortality $(P>0.10)$. The high rate of all treatments (ammonium sulfate $400 \mathrm{~g}$ plant $^{-1}$, ammonium nitrate $264 \mathrm{~g}$, and sodium chloride 180 $\mathrm{g}$, at equivalent salt concentrations) killed greater than $70 \%$ of larkspur plants. We conclude the salt in fertilizers kills tall larkspur, not the nitrogen. It is necessary to place the fertilizer or salt at the base of the plant to concentrate it in the root zone, rather than broadcast it. At the end of the study, bare areas left around the dead tall larkspur plants were only $13 \%$ of the original size of the tall larkspur plants at Yampa Colo. and Cedar Ut., and 46\% at Emery Ut., indicating the surrounding vegetation was quickly filling in the vacated space. The relative cost of materials per plant for both ammonium sulfate and nitrate was $12.9 \notin$, and $2.6 \notin$ for salt.
\end{abstract}

Key Words: Delphinium barbeyi, weed control, herbicide, fertilizer, ammonium sulfate, ammonium nitrate, sodium chloride

Tall larkspur (Delphinium barbeyi Huth) kills more cattle on mountain summer rangeland in the western U.S. than any other plant, disease or predator (Pfister et al. 1999). Herbicides have been used to control larkspur in areas of persistent losses. Cronin and Nielsen (1972) reported 2,4,5-T and Silvex were most effective in controlling tall larkspur, but these herbicides were subsequently banned. Mickelsen et al. (1990) and Ralphs et al. (1992) recommended picloram, metsulfuron, and glyphosate for specific times of the growing season and site conditions.

Environmental sensitivity and the reluctance of federal land management agencies have greatly curtailed the use of pesticides on public lands. Alternative control agents have been investigated. Binns et al. (1971) experimented with 2,4,5-T mixed with ammonium sulfate placed at the base of tall larkspur plants. Near complete control was achieved, but the experimental design pre-

Authors are Rangeland Scientist, USDA/ARS Poisonous Plant Lab, 1150 E. 1400 N., Logan Utah 84341; Range Conservationist, USDA/NRCS, Filmore Utah; and Professor, Southern Utah Univ., Cedar City Utah.

Manuscript accepted 7 Dec. 02.

\section{Resúmen}

La preocupación por los efectos ambientales del uso de pesticidas en tierras públicas ha reducido significativamente el uso de herbicidas para el control del larkspur alto (Delphinium barbeyi Huth). Un método alternativo de control es el uso de sulfato de amonio en la base de las plantas. El objetivo de este estudio fue determinar el mecanismo por el cual los fertilizantes matan al larkspur alto. Nuestra hipótesis es que la sal de los fertilizantes matan la planta. Aplicamos sulfato de amonio, nitrato de amonio y cloruro de sodio a concentraciones equivalents de sal y evaluamos sus efectos en las plantas de larkspur. No hubo diferencia entre tratamientos en relación a la mortalidad de larkspur (P > 0.10). Los tratamientos a altas concentraciones (sulfato de amonio $400 \mathrm{~g}_{\text {plant }}{ }^{-1}$, nitrato de amonio $264 \mathrm{~g}$, y cloruro de sodio 180 $\mathrm{g}$, a concentraciones equivalents de sal) mataron mas del $70 \%$ de las plantas. Concluimos que las sales en los fertilizantes y no el nitrógeno matan al larkspur alto. Es necesario colocar el fertilizante o la sal en la base de la planta para concentrarlo en la zona de raiz, en lugar de dispersarlo. Al final del estudio, las areas descubiertas dejadas alrededor de las plantas muertas de larkspur fueron solamente el $\mathbf{1 3 \%}$ del tamaño original de las plantas de larkspur alto en Yampa Colo. y Cedar, Ut., y $46 \%$ en Emery Ut., indicando que la vegetación de los alrededores ocupo rápidamente el lugar vacante dejado por el larkspur. El costo relativo de los materials por planta para sulfato y nitrato de amonio fue de $12.9 \notin$, y $2.6 \notin$, respectivamente.

cluded separating the effects of the herbicide and fertilizer. Cronin et al. (1977) broadcast ammonium sulfate at the rate of $140 \mathrm{~kg} \mathrm{~N} \mathrm{ha}^{-1}$ in one experiment, and 84 to $1,344 \mathrm{~kg} \mathrm{~N} \mathrm{ha}^{-1}$ in another experiment. They reported no mortality to tall larkspur, but the higher rates burned its leaves and those of associated grasses. Little (1979) claimed the difference in results between the 2 previous experiments was the method of application. $\mathrm{He}$ applied ammonium sulfate to the base of individual plants of duncecap larkspur (D. occidentale $\mathrm{S}$. Watts) in southern Idaho at

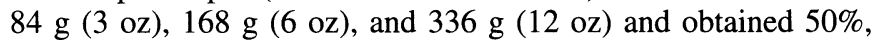
$82 \%$ and $100 \%$ kill (respectively) the following year. He stated the $168 \mathrm{~g}$ rate killed most plants, but the $336 \mathrm{~g}$ rate was required to kill the larger robust plants. Clementson (1999) applied ammonium sulfate to individual plants of tall larkspur in western Colorado at rates of $100 \mathrm{~g}$ ( $1 / 2$ cup), $150 \mathrm{~g}$ (3/4 cup), and $200 \mathrm{~g}$ ( 1 cup). She obtained $100 \%$ control from all 3 treatments the following year, and no larkspur remained in the treated plots 9 years later. This program was applied on several Forest Service allotments to control tall larkspur in patches where cattle losses occurred. 
The objective of this experiment was to evaluate the mechanism by which fertilizers kill larkspur. We hypothesize that the salt from fertilizers kill the plant. We applied ammonium sulfate, ammonium nitrate, and sodium chloride (common salt) to individual tall larkspur plants in amounts containing similar salt equivalents. We predicted that there would be no difference in mortality among treatments.

\section{Methods}

\section{Site Description}

The study was replicated at 3 locations. The Cedar Mountain site was located 40 $\mathrm{km}$ east of Cedar City, Ut. at $2,800 \mathrm{~m}$ elevation (N $37^{\circ} 32.175^{\prime}$, W $\left.112^{\circ} 58.705^{\prime}\right)$ The plant community consisted of tall forbs under an aspen (Populus tremuloides Michx.), with tall larkspur the dominant forb, and western coneflower (Rudbeckia occidentalis Nutt.), sweet cicely (Osmorhiza chilensis H\&A) and meadow rue (Thalictrum fendleri Engelm. ex Gray) as subordinates. Mountain brome (Bromus carinatus Hooker \& Arn.) and slender wheatgrass (Elymus trachycaulus (Link) Gould ex Shinners) were the dominant grasses. The soil was a Faim clay loam; fine, montmorillonitic Argic Pachic Cryoboroll. Detailed descriptions of soils at all 3 locations are in Table 1.

The Emery site was located $34 \mathrm{~km}$ west of Emery, Ut., on the Manti-LaSal National Forest at 3,200 m elevation (N $\left.39^{\circ} 2.454^{\prime}, \mathrm{W} 111^{\circ} 30.543^{\prime}\right)$. The Forest Service habitat type was a tall larkspur / slender wheatgrass/mountain brome complex. Soils were clayey-skeletal, montmorillonitic Pachic Cryoboroll.

The Yampa site was located $16 \mathrm{~km}$ west of Yampa, Colo., on the Routt National Forest (N 40 $\left.11.886^{\prime}, \mathrm{W} 107^{\circ} 2.801^{\prime}\right)$. The habitat type was aspen/tall forb. Tall larkspur was the dominant forb, with cow parsnip (Heracleum lanatum Michx.), sweet cicely, and meadow rue as subdominants. Mountain brome was the dominant grass. Soils were of the Clayburn series and were fine-loamy, mixed Argic Pachic Cryoboroll.

Table 1. Soil characteristics of the study sites at the 3 locations.

\begin{tabular}{lllcccc}
\hline \hline $\begin{array}{l}\text { Location } \\
\text { Emery Ut }\end{array}$ & $\begin{array}{l}\text { Depth } \\
\mathrm{cm}\end{array}$ & Texture & Sand & Silt & $\begin{array}{c}\text { Clay } \\
(\%)\end{array}$ & OM \\
\hline 1998 trt & $0-13$ & Clay loam & 28 & 40 & 32 & 4.5 \\
& $13-36$ & Clay loam & 22 & 44 & 34 & 2.9 \\
& $36+$ & Clay loam & 26 & 40 & 34 & 2.1 \\
& & & & & & \\
1999 trt & $0-23$ & Silty-clay loam & 17 & 46 & 37 & 4.5 \\
& $23-46$ & Clay loam & 23 & 46 & 31 & 3.9 \\
& $46+$ & Silty-clay loam & 15 & 47 & 38 & 3.6 \\
Cedar Ut & $0-10$ & Loam & 40 & 39 & 21 & 10.5 \\
& $10-56$ & Loam & 31 & 43 & 26 & 4.3 \\
& $56-107$ & Clay & 8 & 36 & 56 & 1.6 \\
& $107+$ & Loam & 25 & 50 & 25 & 0.8 \\
Yampa & $0-22$ & & & & & \\
Colo. & $28-76$ & Loam & 38 & 41 & 21 & 11.2 \\
& $76-99$ & Loam & 28 & 45 & 27 & 4.3 \\
& $99-117$ & Silty-clay & 1 & 44 & 55 & 1.4 \\
& & Clay & 16 & 40 & 44 & 1.4 \\
\hline
\end{tabular}

\section{Treatments and Rates}

Ammonium sulfate (sulfate), ammonium nitrate (nitrate), and sodium chloride (salt) were applied to the base of individual plants in amounts equalizing the salt equivalent. The salt index (Calif. Fertilizer Assoc. 2002) accounts for differences in the osmotic potential of each of the different ions. The salt index of each compound was: ammonium sulfate $=69.0$, ammonium nitrate $=104.7$, sodium chloride $=$ 153.8. Since ammonium sulfate was used in past research and had the lowest salt index, it was selected as the standard and was given the relative value of 1.0. The salt index of sulfate (69.0) was divided by the index of nitrate (104.7) and salt (153.8) to obtain the ratio amount relative to sulfate (Table 2).

We selected the ammonium sulfate rates used by Clementson (1999): low rate 100 $\mathrm{g}$ and high rate $200 \mathrm{~g}$. The nitrate ratio was 0.66 or $66 \mathrm{~g}$ for the low rate and 132 $\mathrm{g}$ high rate; and the salt ratio was 0.45 or $45 \mathrm{~g}$ for the low rate and $90 \mathrm{~g}$ for the high rate (Table 2).

Ten transects were established at each location (about $50 \mathrm{~m}$ long and $10 \mathrm{~m}$ apart) and represented blocks or replications of each treatment. Nine distinct plants of uniform size (each about $0.5 \mathrm{~m}^{2}$ foliar cover or area occupied) were selected along each of the transects and marked with wood stakes. The 3 treatments and 2 rates were randomly applied to individual selected plants in a randomized complete block design. In addition to the fertilizers and salt treatments, the granular herbicide tebuthiuron was also applied to individual plants at 3 rates for a total of 9 plants on each transect. The tebuthiuron results are reported elsewhere (Ralphs et al. 2003).

Treatments were applied in 1998 and again to new plants in new transects in 1999. They were applied at Cedar, Ut. on 16 July 1998 and 15 July 1999; Yampa, Colo. 28 July 1998 and 28 July 1999; and Emery, Ut. 14 Aug. 1998 and 5 Aug. 1999. Larkspur plants were in the early flower stage, representing peak production, when treatments were applied and evaluated.

Following the first year evaluation of the 1998 treatments, it appeared that mortality was low for all treatments and did not represent a sufficient range to evaluate the hypothesis. Therefore, we doubled the rates for the 1999 treatments (Table 2). Winter and monthly growing season precipitation for each year are presented in Table 3.

Table 2. Fertilizer treatments, salt index, equivalent mass, and application rates in 1998 and 1999.

\begin{tabular}{|c|c|c|c|c|c|c|c|c|c|}
\hline \multirow[b]{3}{*}{ Treatment } & \multirow[b]{3}{*}{ Salt index } & \multirow[b]{3}{*}{ Ratio } & \multirow[b]{3}{*}{ Mass } & & & \multicolumn{4}{|c|}{ Application Rates } \\
\hline & & & & & & \multicolumn{2}{|c|}{1998} & \multicolumn{2}{|c|}{1999} \\
\hline & & & & \multicolumn{2}{|c|}{ Nitrogen } & 1 & 2 & 2 & 3 \\
\hline & & & (g) & $(\%)$ & $(\mathrm{g})$ & \multicolumn{4}{|c|}{ - } \\
\hline Ammonium sulfate & 69.0 & 1.0 & 100 & 21 & 21 & 100 & 200 & 200 & 400 \\
\hline Ammonium nitrate & 104.7 & 0.66 & 66 & 34 & 22 & 66 & 132 & 132 & 264 \\
\hline Sodium chloride & 153.8 & 0.45 & 45 & 0 & 0 & 45 & 90 & 90 & 180 \\
\hline
\end{tabular}


Table 3. Winter and monthly precipitation during the growing season.

\begin{tabular}{|c|c|c|c|c|c|}
\hline Location & Month & 1998 & 1999 & 2000 & 2001 \\
\hline Emery & $\begin{array}{l}\text { Winter } \\
\text { June } \\
\text { July } \\
\text { Aug } \\
\text { Sep } \\
\text { Total }\end{array}$ & $\begin{array}{r}54.6 \\
7.1 \\
6.1 \\
4.3 \\
10.7 \\
82.8\end{array}$ & $\begin{array}{r}54.4 \\
2.5 \\
6.8 \\
13.0 \\
5.0 \\
77.7\end{array}$ & $\begin{array}{r}40.1 \\
5.0 \\
2.3 \\
6.4 \\
4.6 \\
58.1\end{array}$ & $\begin{array}{r}47.2 \\
2.3 \\
3.8 \\
4.6 \\
1.8 \\
62.2\end{array}$ \\
\hline Cedar & $\begin{array}{l}\text { Winter } \\
\text { June } \\
\text { July } \\
\text { Aug } \\
\text { Sep } \\
\text { Total }\end{array}$ & $\begin{array}{r}65 \\
4.2 \\
8.1 \\
2.4 \\
9.7 \\
89.9\end{array}$ & $\begin{array}{r}41.3 \\
5.3 \\
6.4 \\
7.1 \\
4.7 \\
64.8\end{array}$ & $\begin{array}{r}58.8 \\
2.2 \\
0.6 \\
8.9 \\
1.3 \\
71.8\end{array}$ & $\begin{array}{r}56.3 \\
1.3 \\
4.7 \\
4.7 \\
0.1 \\
67.1\end{array}$ \\
\hline Yampa & $\begin{array}{l}\text { Winter } \\
\text { June } \\
\text { July } \\
\text { Aug } \\
\text { Sep } \\
\text { Total }\end{array}$ & $\begin{array}{r}52.6 \\
2.0 \\
16.6 \\
6.1 \\
2.8 \\
80.0\end{array}$ & $\begin{array}{r}58.2 \\
4.6 \\
0.5 \\
6.6 \\
4.6 \\
74.5\end{array}$ & $\begin{array}{r}50.3 \\
1.8 \\
2.5 \\
5.0 \\
9.9 \\
69.6\end{array}$ & $\begin{array}{r}49.8 \\
1.5 \\
1.3 \\
3.0 \\
4.5 \\
60.2\end{array}$ \\
\hline
\end{tabular}

\section{Data Analysis}

Mortality was evaluated 2 years after the 1998 and 1999 treatments. Treatment years were analyzed separately because of differences in application rates. Categorical data (dead or alive) were analyzed using the logistic procedure of PROC GENMOD and the GLIMMIX macro in the SAS 8e package (SAS 1999). The model evaluated locations, fertilizers, and rate (low and high), and their 2- and 3 -way interactions. Where differences occurred $(\mathrm{P}<0.05)$, means were separated by linear contrasts. A separate analysis was conducted for only rate 2 , which was the same in both treatment years, to evaluate the year effect. The model compared locations, fertilizers, years and their interactions.

The impact on the environment by the fertilizer and salt treatments was estimated by the size of the bare areas left after the tall larkspur plants died. The bare area surrounding the dead tall larkspur plant was estimated by the area of a circle, with the radius calculated by summing the diameter of the bare area at $90^{\circ}$ angles and dividing by 4 . These measurements were taken for
3 years following the 1998 treatment and 2 years following the 1999 treatment. Many tall larkspur plants took 2 years to die, therefore the size of the bare area at the end of the study was the best indicator of environmental impact of the treatments and was used as the response variable in the mixed model. Data were analyzed by a mixed ANOVA using unstructured covariance (SAS 1999) to compare locations, treatments, and treatment year. There were no differences between treatment rates $(P$ $>0.23$ ), allowing comparison between treatment years. Measurement of bare areas was not continued beyond 2001 because of the difficulty of locating the stakes and treated areas due to the encroachment of the adjacent vegetation.

\section{Results}

There were no differences in mortality among treatments $(P>0.10$, Table 4, grand treatment mean). This supports our hypothesis that it was not the nitrogen in the fertilizer, but the salt in the fertilizers that kill the plants. The amount of nitrogen applied was similar between the ammonium fertilizers, but there was no nitrogen in the salt treatment (Table 2). Furthermore, the actual quantity of treatment material placed on the plants varied by more than $100 \%$, yet mortality was similar.

There was only 1 significant interaction; location-by-treatment in the 1998 applications $(\mathrm{P}<0.0001)$. The salt treatment

Table 4. Mortality of tall larkspur plants 2 years after treating with fertilizers and salt applied at equal salt concentrations in 1998 and 1999.

\begin{tabular}{|c|c|c|c|c|c|c|c|c|c|}
\hline \multirow[b]{2}{*}{ Location } & \multirow[b]{2}{*}{ Rate } & \multicolumn{3}{|c|}{1998 Treatment Year } & \multicolumn{5}{|c|}{1999 Treatment Year } \\
\hline & & Nitrate & Sulfate & Salt & $\begin{array}{l}\text { Location } \\
\text { mean }\end{array}$ & Nitrate & Sulfate & Salt & $\begin{array}{c}\text { Location } \\
\text { mean }\end{array}$ \\
\hline \multirow[t]{4}{*}{ Emery } & 1 & 30 & 40 & 0 & $--(\%$ & lity)----- &.--- & & --_-_--_- \\
\hline & 2 & 70 & 70 & 10 & & 50 & 40 & 50 & \\
\hline & 3 & & & & & 90 & 80 & 70 & \\
\hline & mean & 50 & 55 & 5 & $43^{b}$ & 70 & 60 & 60 & $64^{\mathrm{a}}$ \\
\hline \multirow[t]{4}{*}{ Cedar } & 1 & 20 & 10 & 50 & & & & & \\
\hline & 2 & 70 & 30 & 50 & & 67 & 70 & 30 & \\
\hline & 3 & & & & & 90 & 90 & 80 & \\
\hline & mean & 45 & 20 & 50 & $45^{b}$ & 79 & 80 & 55 & $72^{\mathrm{a}}$ \\
\hline \multirow[t]{4}{*}{ Yampa } & 1 & 70 & 89 & 80 & & & & & \\
\hline & 2 & 80 & 100 & 90 & & 40 & 50 & 50 & \\
\hline & 3 & & & & & 80 & 78 & 80 & \\
\hline & mean & 75 & 94 & 85 & $85^{\mathrm{a}}$ & 60 & 64 & 65 & $63^{\mathrm{a}}$ \\
\hline Treatment mean & & $57^{\mathrm{a}}$ & $56^{\mathrm{a}}$ & $47^{\mathrm{a}}$ & & & $70^{\mathrm{a}}$ & $68^{a}$ & $60^{\mathrm{a}}$ \\
\hline \multirow[t]{4}{*}{ Rate mean } & & 1998 & 1999 & & & & & & \\
\hline & 1 & $50^{c}$ & & & & & & & \\
\hline & 2 & $63^{\mathrm{dE}}$ & $50^{\mathrm{cF}}$ & & & & & & \\
\hline & 3 & & $82^{d}$ & & & & & & \\
\hline
\end{tabular}


Table 5. Initial size (aerial cover) of larkspur plants $( \pm \mathrm{SE})$ and bare area surrounding dead larkspur plants at end of study.

\begin{tabular}{|c|c|c|c|c|c|c|}
\hline \multirow[b]{2}{*}{ Location } & \multirow[b]{2}{*}{$\begin{array}{l}\text { Treatment } \\
\text { year }\end{array}$} & \multicolumn{5}{|c|}{ Bare area following treatments } \\
\hline & & $\begin{array}{l}\text { Initial plant } \\
\text { size }\end{array}$ & Nitrate & Sulfate & Salt & $\begin{array}{c}\text { Location } \\
\text { mean }\end{array}$ \\
\hline Emery & $\begin{array}{l}1998 \\
1999 \\
\text { mean }\end{array}$ & $\begin{array}{l}3,204 \pm 236 \\
4,901 \pm 267\end{array}$ & $\begin{array}{l}1,050 \pm 89 \\
2,502 \pm 218 \\
1,776\end{array}$ & $\begin{array}{l}1,174 \pm 145 \\
2,762 \pm 230 \\
1,968\end{array}$ & $\begin{array}{l}1,723 \pm 74 \\
2,003 \pm 245 \\
1,863\end{array}$ & $1,869 \mathrm{a}$ \\
\hline Cedar & $\begin{array}{l}1998 \\
1999 \\
\text { mean }\end{array}$ & $\begin{array}{l}5,823 \pm 346 \\
4,765 \pm 305\end{array}$ & $\begin{array}{l}629 \pm 224 \\
673 \pm 70 \\
651\end{array}$ & $\begin{array}{l}500 \pm 201 \\
772 \pm 104 \\
636\end{array}$ & $\begin{array}{l}476 \pm 69 \\
807 \pm 128 \\
641\end{array}$ & $643 b$ \\
\hline Yampa & $\begin{array}{l}1998 \\
1999 \\
\text { mean }\end{array}$ & $\begin{array}{l}5,549 \pm 405 \\
4,991 \pm 280\end{array}$ & $\begin{array}{c}587 \pm 164 \\
481 \pm 86 \\
534\end{array}$ & $\begin{array}{l}703 \pm 174 \\
543 \pm 72 \\
623\end{array}$ & $\begin{array}{c}1,171 \pm 300 \\
942 \pm 297 \\
1,056\end{array}$ & $738 \mathrm{~b}$ \\
\hline Grand & mean & 4,872 & $987 \mathrm{a}$ & $1,076 \mathrm{a}$ & $1,187 \mathrm{a}$ & \\
\hline
\end{tabular}

${ }^{\mathrm{ab}}$ Difference among fertilizer treatments in rows, or locations in columns differ $(\mathrm{P}<0.05)$.

gave very low mortality at Emery, and the sulfate treatment gave low mortality at Cedar City (Table 4). Both of these locations received less precipitation in August 1998 following application of treatments than in subsequent years (Table 3 ), but these treatments were equally effective in other locations and years.

There was a rate difference in both years $(\mathrm{P}<0.0016$, Table 4 , grand rate mean $)$; the higher dose killed more plants in both years. There was a difference between treatment years when compared at the same rate $(P=0.02)$. Rate No. 2 in the 1998 treatment year caused higher mortality than in the 1999 treatment year. This was due almost entirely to the very high mortality from all 3 treatments at Yampa in the 1998 applications $(\mathrm{P}<0.0001$, Table 4). Yampa had more rain during the growing season in 1998 than in 1999 (Table 3). The soil was saturated from $16.6 \mathrm{~cm}$ of rain received before the treatments were applied in July, thus the 6.1 $\mathrm{cm}$ of rain in August may have distributed the salt rapidly throughout the root zone. There was no difference among locations for the 1999 applications.

Where tall larkspur plants died, bare areas remained (Table 5). There was no difference in size of bare areas between fertilizer treatments or rates of application $(\mathrm{P}>0.10)$. The Emery site had larger bare areas than the other locations $(\mathrm{P}<$ $0.0001)$, due perhaps to the clay soil retaining the salts from the treatments. There was a location-by-treatment year interaction $(\mathrm{P}<0.001)$; bare ground was greater in the 1999 treatment compared to the 1998 treatment at Emery, but was similar between years at the other locations. At the end of the experiment, the bare areas were only $13 \%$ of the original size of the larkspur plants at Cedar and Yampa, and $46 \%$ of the size of the original plants at Emery. Adjacent vegetation (mountain brome, slender wheatgrass and meadow rue) was encroaching upon the areas previously occupied by tall larkspur and is expected to quickly cover the bare areas. The relatively flat surface prevented soil erosion from these bare spots while they revegetated.

\section{Discussion and Conclusions}

We conclude the salt in fertilizers killed tall larkspur, not the nitrogen. We also found that it is necessary to place the fertilizer or salt at the base of the plant to concentrate the salts as they are leached into the root zone. This confirms the results of Little (1979) and Clementson (1999). The lack of effect of fertilizer reported by Cronin et al. (1977) was apparently due to the broadcast application of the fertilizers.

Salinity adversely affects plants by the combined effects of reducing and stopping metabolic processes, ion toxicity, and chemically reducing soil water availability; cumulatively resulting in mortality (Miller and Doescher 1995, Marschner 1995). Excessive uptake of salts inhibits enzyme activity resulting in disruption of protein synthesis and inadequate energy from photophosphoralation. The resulting ionic imbalance increases membrane permeability and disrupts osmoregulation, resulting in direct ion toxicity. The total concentration of solute particles in the soil water solution surrounding the plant causes the osmotic potential to become more negative, lowering soil water potential and making it increasingly more difficult for the plant to take up water (Richards 1969). The signs of stress in the treated tall larkspur plants did not differ among the treatments: stunted growth, curling and crum- pled leaves, and necrotic brown spots, especially along the leaf edges. Adjacent tall larkspur plants did not show signs of water stress or salt toxicity, and there was no mortality from other causes.

The high rate of all treatments killed greater than $70 \%$ of tall larkspur plants. These rates were sulfate, $400 \mathrm{~g}$ ( 2 cups); nitrate, $264 \mathrm{~g}$ ( 1 1/3 cup); and salt, $180 \mathrm{~g}$ ( $2 / 3$ cup). The relative cost of the chemical per plant for both ammonium sulfate and nitrate was $12.9 \phi$, and $2.6 \phi$ for salt. The amount of salt required to kill a plant is lower and the cost is cheaper, but fertilizers may give a short term boost of fertility to surrounding vegetation. In comparison, spot treatment to individual plants using the herbicide tebuthiuron was $5 \notin$ per plant (Ralphs et al. 2003).

Another practice to manage larkspur has been to graze it with sheep. Sheep are 4 to 6 times more resistant to larkspur poisoning than cattle (Olsen 1978). Many larkspur-infested allotments were allocated to sheep during adjudication as a solution to the larkspur problem. With the decline in the sheep industry, many sheepmen are seeking to convert back to cattle if the risk of larkspur poisoning can be reduced. Using salt or fertilizers to control tall larkspur, though labor intensive, is relatively inexpensive for the material, and poses little environmental risk compared to broadcast herbicides used under aspen and on public lands.

\section{Literature Cited}

Binns, W., L.F. James, and A.E. Johnson. 1971. Control of larkspur with herbicides plus nitrogen fertilizer. J. Range Manage. 24:110-113.

California Fertilizer Assoc. 2002. Western fertilizer handbook. 9 Ed. Interstate Publishers, Danville, Ill. 
Clementson, C. 1999. Tall larkspur control with ammonium sulphate fertilizer. Rangelands 21:3-5.

Cronin E.H. and D.B. Nielsen. 1972. Controlling tall larkspur on snowdrift areas in the subalpine zone. J. Range Manage. 25:213-216.

Cronin, E.H., J.E. Bowns, and A.E. Johnson. 1977. Herbicides, nitrogen, and control of tall larkspur under aspen trees. J. Range Manage. 30:420-422.

Little, W.J. 1979. Controlling tall larkspur with ammonium sulfate fertilizer. Range Improvement Notes, USDA Forest Service Intermountain Region, Ogden Ut. July 1979.

Marschner, H. 1995. Mineral nutrition of higher plants, $2^{\text {nd }}$ edition. p.657-665. Academic Press, New York.
Mickelsen, L.V., M.H. Ralphs, D.L. Turner, J.O. Evans, and S.A. Dewey. 1990. Herbicidal control of duncecap larkspur (Delphinium occidentale). Weed Sci. 38:153-157.

Miller, R.F. and P.S. Doescher. 1995. Plant adapations to saline environments. p. 440-478, In:D.J. Bedunah and R.E. Sosebee (eds.) Wildland plants: physiological ecology and developmental morphology. Soc. for Range Manage., Denver Colo.

Olsen, J.D. 1978. Tall larkspur poisoning in cattle and sheep. J. Amer. Vet. Med. Asoc. 173:762-765.

Pfister, J.A., D.R. Gardner, K.E. Panter, G.D. Manners, M.H. Ralphs, B.L. Stegelmeier, and T.K. Schoch. 1999. Larkspur (Delphinium spp.) poisoning in livestock. J. Natural Toxins 8:81-94.
Ralphs, M.H., J.O. Evans, and S.A. Dewey. 1992. Timing of herbicide applications for control of larkspurs (Delphinium spp.). Weed Sci. 40:264-269.

Ralphs, M.H., L.Woolsey, and J.E. Bowns. 2003. Control of tall larkspur with tebuthiuron. Weed Sci. (in review).

Richards, L.A. 1969. Diagnosing and improvement of saline and alkali soils. USDA Agr. Handb. 60. Wash., D.C.

SAS. 1999. Statistical Analysis Systems 8e. SAS Institute, Cary N.C. 